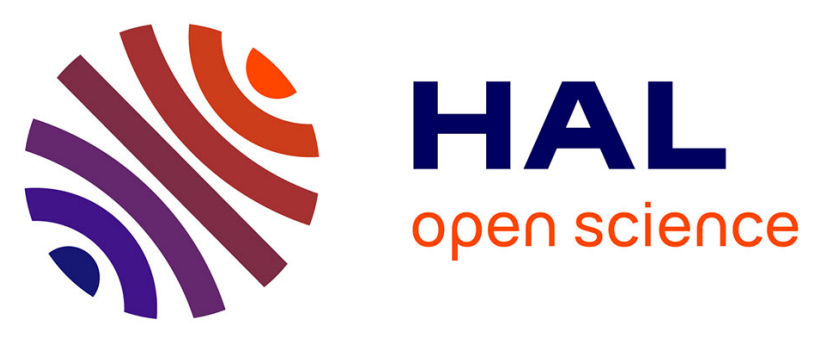

\title{
Determination of Interleukin-6 (IL-6) in Cerebrospinal Fluid: Potential Role for the Evaluation of the Vital Prognosis in Bacterial Meningitis
}

\author{
Ibrahim Dan Dano, Odile Missi Oukem-Boyer, Mamane Ali El-Hadji, Ali \\ El-Hadji Mamane
}

\section{To cite this version:}

Ibrahim Dan Dano, Odile Missi Oukem-Boyer, Mamane Ali El-Hadji, Ali El-Hadji Mamane. Determination of Interleukin-6 (IL-6) in Cerebrospinal Fluid: Potential Role for the Evaluation of the Vital Prognosis in Bacterial Meningitis. Journal of Biological Sciences, 2016, 10.3923/jbs.2016 . pasteur01330469

\section{HAL Id: pasteur-01330469 \\ https://hal-riip.archives-ouvertes.fr/pasteur-01330469}

Submitted on 10 Jun 2016

HAL is a multi-disciplinary open access archive for the deposit and dissemination of scientific research documents, whether they are published or not. The documents may come from teaching and research institutions in France or abroad, or from public or private research centers.
L'archive ouverte pluridisciplinaire HAL, est destinée au dépôt et à la diffusion de documents scientifiques de niveau recherche, publiés ou non, émanant des établissements d'enseignement et de recherche français ou étrangers, des laboratoires publics ou privés. 


\title{
Determination of Interleukin-6 (IL-6) in Cerebrospinal Fluid: Potential Role for the Evaluation of the Vital Prognosis in Bacterial Meningitis
}

\author{
${ }^{1}$ Ibrahim Dan Dano, ${ }^{1}$ Odile Ouwe Missi Oukem-Boyer, ${ }^{1}$ Ali Elhadji Mahamane and ${ }^{2}$ Hassimi Sadou \\ ${ }^{1}$ Centre de Recherche Medicale et Sanitaire (CERMES), 634 Boulevard de la Nation YN034, B.P. 10887, Niamey, Niger \\ ${ }^{2}$ Faculte des Sciences et Techniques, Universite Abdou Moumouni, B.P. 10662, Niamey, Niger
}

\section{Abstract}

Background: To analyze whether the determination of interleukin- 6 levels in cerebrospinal fluid is useful as a biomarker for the severity of bacterial meningitis. Methodology: Cerebrospinal fluid was obtained from 120 patients aged 0-15 years with meningitis. They were classified as having bacterial meningitis $(n=85)$ or aseptic meningitis $(n=35)$ according to the cerebrospinal fluid white blood cell count, microbiological culture and molecular methods. Interleukin-6 levels were determined by enzyme-linked immunosorbent assay. Results: No significant change in the mean interleukin- 6 level on the basis of clinical signs was observed in patients with bacterial meningitis. However, the cerebrospinal fluid total protein level was elevated in patients with alertness problems $\left(3.41 \pm 2.26 \mathrm{~g} \mathrm{~L}^{-1}\right)$. There was a significant correlation (Pearson correlation $\mathrm{p} \leq 0.05$ ) between the cerebrospinal fluid glucose and total protein levels in patients with bacterial meningitis. The mean cerebrospinal fluid interleukin-6 level $\left(4,472.0 \pm 2,494.52 \mathrm{pg} \mathrm{mL}^{-1}\right)$ in patients with bacterial meningitis whose disease outcome was fatal was significantly higher $(p \leq 0.05)$ than that of those who survived the disease $\left(2,983.28 \pm 2,612.13 \mathrm{pg} \mathrm{mL}^{-1}\right)$. Conclusion: Interleukin- 6 is a potential biomarker for identifying bacterial meningitis patients with a high risk of death who require intensive care.

Key words: Interleukin-6, cerebrospinal fluid, prognosis, bacterial meningitis

Received: $\quad$ Accepted: Published:

Citation: Ibrahim Dan Dano, Odile Ouwe Missi Oukem-Boyer, Ali Elhadji Mahamane and Hassimi Sadou, 2016. Determination of interleukin-6 (IL-6) in cerebrospinal fluid: Potential role for the evaluation of the vital prognosis in bacterial meningitis. J. Biol. Sci., CC: CC-CC.

Corresponding Author: Ibrahim Dan Dano, Centre de Recherche Medicale et Sanitaire (CERMES), 634 Boulevard de la Nation YN034, B.P. 10887, Niamey, Niger Tel: +227 20752040 Fax: +227 20753180

Copyright: ( 2016 Ibrahim Dan Dano et al. This is an open access article distributed under the terms of the creative commons attribution License, which permits unrestricted use, distribution and reproduction in any medium, provided the original author and source are credited.

Competing Interest: The authors have declared that no competing interest exists.

Data Availability: All relevant data are within the paper and its supporting information files. 


\section{INTRODUCTION}

Acute meningitis is responsible for rampant epidemics each year in Africa in the "African meningitis belt". This meningitis, primarily due to a meningococcus, remains a public health problem. The establishment of new biomarkers that allow the rapid and precise diagnosis of the disease while also indicating its severity could improve care and reduce mortality. Certain cytokines, such as interleukin-1 (IL-1), interleukin-6 (IL-6), interleukin-8 (IL-8), tumor necrosis factor- $\alpha$ (TNF) and interferon (IFN) may be responsible for the severe inflammatory reaction associated with acute meningitis. Thus, there may be a correlation between cytokine concentrations in the cerebrospinal fluid (CSF) and morbidity and mortality ${ }^{2,3}$. The IL-6 is a potential marker for the diagnosis of bacterial meningitis ${ }^{4-7}$. However, inflammatory and anti-inflammatory cytokines are rarely measured for the diagnosis or prognosis of meningitis ${ }^{8}$. A new CSF biomarker that permits the differential diagnosis of meningitis and prognostic evaluation of the disease could improve the management of meningitis.

\section{MATERIALS AND METHODS}

This is a prospective, observational, transversal and non-blinded study. Patient inclusion was conducted at the Emergency Pediatric department of the National Hospital of Niamey (HNN) from February-April, 2015. Clinical patient information and microbiological culture results for patients and their CSF glucose and CSF protein levels, determined by the medical biology and biochemistry laboratories of the HNN were collected from a data collection sheet. Aliquots of the CSF supernatant obtained after centrifugation at $4000 \mathrm{rpm}$ for 5 min was conserved at $-20^{\circ} \mathrm{C}$ for IL- 6 measurements and bacterial identification by molecular biology at the Medical and Health Research Center (CERMES).

Patients: This study included 120 patients with an average age of $6.8 \pm 4.67$ years of which 35 had aseptic meningitis (leukocyte count $>10$ cells $\mathrm{mm}^{-3}$ and no bacteria identified by culture or molecular biology) and 85 had bacterial meningitis identified by both microbiological culture and molecular biology. The CSF sampling was performed at admission before the start of antibiotic therapy with ceftriaxone.

Measurement of CSF biomarkers: Glucose (Cypress Diagnostics, Langdorp, Belgium) and protein (Sprinreact, Sant
Esteve de Bas, Spain) contents of the CSF supernatant were determined using an enzymatic, colorimetric method ${ }^{9-14}$.

An enzyme-linked immunosorbent assay (ELISA) method using the Human IL-6 ELISA (EH2IL65) kit (Thermo Scientific, USA) was used to measure IL- 6 in the CSF supernatant. Each sample was analyzed in duplicate and the absorbance of the plates measured at $450 \mathrm{~nm}$. The test has a sensitivity $<1 \mathrm{pg} \mathrm{mL}^{-1}$ and requires $50 \mu \mathrm{L}$ of CSF supernatant. The results are expressed in $\mathrm{pg} \mathrm{mL}^{-1}$.

Bacteriological and molecular identification: Bacteriological identification involved culture on polyvitex chocolate agar or blood agar using an API NH gallery for Neisseria meningitidis and Haemophilus influenzae and the Alere BinaxNOW ${ }^{\circledR}$ Streptococcus pneumoniae Antigen Card Kit (Alere Inc, USA) for Streptococcus pneumoniae.

A conventional Multiplex Polymerase Chain Reaction $(\mathrm{PCR})$ was used to identify the three principle bacteria responsible for bacterial meningitis: Neisseria meningitidis (crgA gene), Streptococcus pneumoniae (lytA gene) and Haemophilus influenzae (bexA gene). The genogroup of Neisseria meningitidis was determined by multiplex PCR that first identifies the $A, X$ and $W$ genogroups and then the $Y$ and $C$ genogroups for those that are negative in the first $P C R^{15-17}$.

Statistics: The IBM SPSS Statistics vs 20 software was used for statistical analysis. The Mann-Whitney $U$ test was performed to compare the groups. The Pearson correlation was determined only for patients with results for the three biomarkers. The $p \leq 0.05$ was considered to be significant.

\section{RESULTS}

The distribution of the patients according to age and gender and the mean values of the biomarkers depending on the type of meningitis, are summarized in Table 1. The principal bacterium identified in the cases of bacterial meningitis was Neisseria meningitides (97.6\% of cases): $77.6 \%$ were serogroup C, $11.8 \%$ serogroup $W$ and $8.2 \%$ undetermined. Only two cases of $S$. pneumoniae (2.4\%) were identified. There was a significant difference $(p<0.01)$ between the patients with bacterial meningitis and those with aseptic meningitis for the CSF IL-6 concentration $\left(3,538.69 \pm 2,560.78 \mathrm{pg} \mathrm{mL} \mathrm{mL}^{-1}\right.$ versus $\left.332.51 \pm 470.69 \mathrm{pg} \mathrm{mL}^{-1}\right)$, CSF glucose $\left(1.31 \pm 1.59 \mathrm{mmol} \mathrm{L}^{-1}\right.$ versus $3.01 \pm 2.09 \mathrm{mmol} \mathrm{L}^{-1}$ ) and CSF protein levels (3.09 $\pm 2.79 \mathrm{~g} \mathrm{~L}^{-1}$ versus $\left.1.70 \pm 1.79 \mathrm{~g} \mathrm{~L}^{-1}\right)$. Biomarker values associated with various clinical symptoms were determined: (1) Mean CSF protein levels were significantly higher in 
Table 1: Population characteristics and biomarkers of patients included in the

\begin{tabular}{lll}
\multicolumn{1}{c}{ study } & & \\
\hline Variable $^{\prime}$ & Aseptic meningitis & Bacterial meningitis \\
\hline Patients $^{\mathrm{a}}$ & $35(29.2 \%)$ & $85(70.8 \%)$ \\
Male $^{\mathrm{a}}$ & $17(14.2 \%)$ & $42(35 \%)$ \\
Female $^{\mathrm{a}}$ & $18(15 \%)$ & $43(35.8 \%)$ \\
Age $^{\text {years }}{ }^{\mathrm{b}}$ & $5.43(0-14)$ & $8.43(1-15)$ \\
CSF protein level $^{\mathrm{c}}$ & $1.70 \pm 1.79(\mathrm{n}=18)$ & $3.09 \pm 2.79(\mathrm{n}=65)$ \\
CSF glucose & $3.01 \pm 2.09(\mathrm{n}=18)$ & $1.31 \pm 1.59(\mathrm{n}=65)$
\end{tabular}

level $\left(\mathrm{mmol} \mathrm{L}^{-1}\right)^{c}$

CSF IL-6 $\left(\mathrm{pg} \mathrm{mL}^{-1}\right)$ level $^{\mathrm{c}} \quad 332.51 \pm 470.69(\mathrm{n}=35) \quad 3,538.69 \pm 2560.78(\mathrm{n}=85)$ aResults are expressed as the number of patients (\% of total number of patients), ${ }^{b}$ Mean (minimum-maximum), cMean \pm SD (number of patients) and N: Number of patients bacterial meningitis patients with alertness problems (3.41 $\pm 2.26 \mathrm{~g} \mathrm{~L}^{-1}, \mathrm{p} \leq 0.05$ ) (Table 2) and (2) IL-6 levels were higher in aseptic meningitis patients with convulsions (1104.79 $\pm 1534.16 \mathrm{pg} \mathrm{mL}^{-1}, \mathrm{p} \leq 0.05$ ) (Table 3). There was a significant correlation (Pearson correlation, $p<0.05$ ) between CSF glucose and protein levels, but not IL-6, in patients with bacterial meningitis. The mean concentration of IL- 6 at admission was higher in patients for whom the disease outcome was death than in patients who survived the disease $\left(4,472.0 \pm 2,494.52 \mathrm{pg} \mathrm{mL}^{-1}\right.$ versus 2,983.28 2 2,612.13 $\mathrm{pg} \mathrm{mL}^{-1}, \mathrm{p} \leq 0.05$ ) (Table 4).

Table 2: CSF IL-6, glucose and total protein values according to clinical signs of patients with bacterial meningitis

\begin{tabular}{|c|c|c|c|}
\hline Variable & CSF IL-6 (pg mL-1) & CSF glucose $\left(\mathrm{mmol} \mathrm{L}^{-1}\right)$ & CSF protein $\left(\mathrm{g} \mathrm{L}^{-1}\right)$ \\
\hline \multicolumn{4}{|c|}{ Duration of the disease } \\
\hline$\leq 3$ days & $3,611.16 \pm 2554.29(n=71)$ & $1.26 \pm 1.44(n=56)$ & $2.78 \pm 2.15(n=56)$ \\
\hline$>3$ days & $2,835.92 \pm 2350.75(n=5)$ & $0.07 \pm 0.04(n=2)$ & $11.21 \pm 9.59(n=2)$ \\
\hline \multicolumn{4}{|l|}{ Fever } \\
\hline Yes & $3,832.37 \pm 2611.03(n=44)$ & $1.44 \pm 1.79(n=36)$ & $3.38 \pm 3.26(n=36)$ \\
\hline No & $2,893.78 \pm 2308.59(n=27)$ & $0.88 \pm 0.94(n=19)$ & $3.00 \pm 2.29(n=19)$ \\
\hline \multicolumn{4}{|c|}{ Neck stiffness } \\
\hline Yes & $3,600.09 \pm 2579.48(n=57)$ & $1.34 \pm 1.42(n=43)$ & $3.220 \pm 3.11(n=43)$ \\
\hline No & $3,235.05 \pm 2580.09(n=24)$ & $1.24 \pm 1.96(n=20)$ & $2.670 \pm 2.13(n=20)$ \\
\hline \multicolumn{4}{|c|}{ Convulsion } \\
\hline Yes & $3,644.35 \pm 2699.52(n=35)$ & $1.43 \pm 1.82(n=23)$ & $3.47 \pm 2.49(n=23)$ \\
\hline No & $3,375.96 \pm 2488.92(n=40)$ & $1.24 \pm 1.47(n=40)$ & $2.80 \pm 3.01(n=40)$ \\
\hline \multicolumn{4}{|c|}{ Alertness problems } \\
\hline Yes & $3,541.42 \pm 2691.91(n=43)$ & $1.24 \pm 1.40(n=35)$ & $3.41 \pm 2.26^{*}(n=35)$ \\
\hline No & $3,435.93 \pm 2457.17(n=38)$ & $1.40 \pm 1.84(n=28)$ & $2.59 \pm 3.40(n=28)$ \\
\hline \multicolumn{4}{|l|}{ Purpura } \\
\hline Yes & $1.36 \pm 0.92(n=6)$ & $2.31 \pm 2.12(n=6)$ & $2,894.130 \pm 3273.18(n=6)$ \\
\hline No & $1.31 \pm 1.66(n=57)$ & $3.12 \pm 2.90(n=57)$ & $3,557.440 \pm 2449.44(n=73)$ \\
\hline
\end{tabular}

Table 3: CSF IL-6, glucose and total protein values according to clinical signs of patients with aseptic meningitis

\begin{tabular}{|c|c|c|c|}
\hline Variable & CSF IL-6 (pg mL $\left.{ }^{-1}\right)$ & CSF glucose $\left(\mathrm{mmol} \mathrm{L}^{-1}\right)$ & CSF protein $\left(\mathrm{g} \mathrm{L}^{-1}\right)$ \\
\hline \multicolumn{4}{|c|}{ Duration of the disease } \\
\hline$\leq 3$ days & $830.30 \pm 1308.69(n=27)$ & $3.03 \pm 2.20(n=16)$ & $1.59 \pm 1.79(n=16)$ \\
\hline$>3$ days & $17.37(n=1)$ & $3.74(n=1)$ & $0.24(n=1)$ \\
\hline \multicolumn{4}{|l|}{ Fever } \\
\hline Yes & $816.74 \pm 1257.22(n=17)$ & $2.92 \pm 2.0(n=8)$ & $1.17 \pm 1.49(n=8)$ \\
\hline No & $276.55 \pm 397.96(n=9)$ & $3.30 \pm 1.92(n=6)$ & $1.09 \pm 1.43(n=6)$ \\
\hline \multicolumn{4}{|c|}{ Neck stiffness } \\
\hline Yes & $1,344.25 \pm 1585.50(n=11)$ & $2.29 \pm 1.76(n=5)$ & $2.12 \pm 1.76(n=5)$ \\
\hline No & $435.9100 \pm 860.36(n=21)$ & $3.39 \pm 2.26(n=12)$ & $1.25 \pm 1.78(n=12)$ \\
\hline \multicolumn{4}{|c|}{ Convulsion } \\
\hline Yes & $1,104.79 \pm 1534.16^{*}(n=13)$ & $2.49 \pm 2.74(n=8)$ & $2.15 \pm 2.13(n=8)$ \\
\hline No & $504.1400 \pm 929.97(n=19)$ & $3.58 \pm 1.38(n=9)$ & $0.94 \pm 1.22(n=9)$ \\
\hline \multicolumn{4}{|c|}{ Alertness problems } \\
\hline Yes & $760.16 \pm 1279.82(n=14)$ & $3.31 \pm 2.41(n=8)$ & $1.00 \pm 1.10(n=8)$ \\
\hline No & $738.81 \pm 1219.90(n=18)$ & $2.85 \pm 1.98(n=9)$ & $1.96 \pm 2.16(n=9)$ \\
\hline
\end{tabular}

${ }^{*} \mathrm{p} \leq 0.05$ and $\mathrm{n}$ : Number of patients

Table 4: IL-6 values according to disease outcome of patients with bacterial meningitis

\begin{tabular}{llll}
\hline Variable & CSF IL-6 $\left(\mathrm{pg} \mathrm{mL}^{-1}\right)$ & CSF glucose $\left(\mathrm{mmol} \mathrm{L}^{-1}\right)$ & CSF protein $(\mathrm{g} \mathrm{L}-1)^{-1}$ \\
\hline Death & $4,472.00 \pm 2494.52^{*}(\mathrm{n}=21)$ & $1.78 \pm 2.18(\mathrm{n}=13)$ & $4.47 \pm 4.82(\mathrm{n}=13)$ \\
Survival & $2,983.28 \pm 2612.13(\mathrm{n}=48)$ & $0.87 \pm 1.05(\mathrm{n}=33)$ & $3.19 \pm 2.0(\mathrm{n}=33)$ \\
\hline
\end{tabular}

${ }^{*} \mathrm{p} \leq 0.05$ and $\mathrm{n}$ : Number of patients 


\section{DISCUSSION}

The diagnosis of meningitis is primarily based on clinical examination and the analysis of CSF cytology and CSF glucose and protein levels ${ }^{18,19}$. Other biomarkers of CSF including cytokines have been explored to increase the number of available biological examinations that are informative about the intensity of inflammation in the subarachnoid space ${ }^{20}$. The central hypothesis of this study is a possible link between the IL- 6 concentration in the CSF and both the clinical signs and outcome of the disease. The results obtained show that the clinical signs of bacterial meningitis are independent of the IL- 6 concentration. In contrast, CSF protein is higher in patients with than without alertness problems. The increase in CSF protein levels following inflammation in the subarachnoid space is one of the physiopathological mechanisms that leads to nerve damage ${ }^{21}$. This nerve damage may be the direct consequence of bacterial toxicity or due to the indirect effect of cytokine secretion $^{22,23}$. Alertness problems associated with bacterial meningitis are a consequence of the increased protein concentration in the CSF and convulsions in aseptic meningitis a consequence of increased IL- 6 in the CSF. Nevertheless, the CSF IL- 6 concentration is significantly higher in bacterial than aseptic meningitis ${ }^{21,24,25}$. A link between the increase in the CSF IL- 6 concentration in aseptic meningitis and nerve damage has been reported ${ }^{21}$, this high IL- 6 concentration does not correlate with CSF glucose and protein levels. This study did not find a relation between the CSF IL- 6 concentration and the duration of the illness and fever. In contrast, Hseih et al. ${ }^{4}$ found a significant increase in the CSF IL-6 concentration if the fever lasted longer than three days for both bacterial and aseptic meningitis. In this study, a link between high mean CSF IL- 6 concentration and a fatal outcome of the disease was found. According to Vazquez et al. ${ }^{26}$, an IL-6 concentration in the CSF above $1000 \mathrm{pg} \mathrm{dL}^{-1}$ is associated with high morbidity and mortality independent of the clinical signs of the disease. In contrast, Misra et al. ${ }^{27}$ reported that the CSF IL-6 concentration does not correlate with the stage of the disease, the severity, or the outcome in patients with tuberculin meningitis. The IL- $6, \mathrm{TNF} \alpha$ and IL-1 $\beta$ are the principal cytokines secreted first and act in synergy to stimulate a cascade of inflammatory mediators ${ }^{28}$. This inflammatory reaction is partially responsible for the physiopathological consequences of bacterial meningitis such as the stimulation of protein secretion (exudation), fever, leukocyte infiltration ${ }^{29}$ and neurological damage: Cerebral edema, cerebral hypoperfusion, nerve damage ${ }^{23}$. The association between the severity of inflammation in the subarachnoid space and the mortality of meningitis has already been reported in experimental animal models of bacterial meningitis ${ }^{30,31}$. There is also a correlation between the CSF IL- 6 concentration and neurological damage in cases of aseptic meningitis ${ }^{21,32}$. Consequently, the use of dexamethasone has been suggested to reduce the intensity of the inflammatory reaction in the subarachnoid space and the negative effects ${ }^{33}$.

This study coincided with a major meningitis epidemic ${ }^{34}$. The capacity of the National Hospital of Niamey is limited and some patients were redirected to other centers such that we do not know the outcome, also, in these conditions of overload, CSF was not collected or not tested for some patients. Medical follow-up of patients is not considered in this study. However, follow-up of these patients would be valuable to evaluate the clinical value of assaying CSF IL-6.

\section{CONCLUSION}

The IL- 6 is a potential biomarker for the identification of bacterial meningitis patients with an elevated risk of dying and who need intensive care. The IL-6 testing may identify patients who do not require hospitalization and could be treated at home, thereby freeing-up hospital beds for serious cases, particularly during epidemics.

\section{ACKNOWLEDGMENTS}

We warmly thank the personnel of the BacteriologyVirology Unit of CERMES, the personnel of the Pediatric Emergency Department, the Medical Biology Laboratory, the Biochemistry Laboratory and the Epidemiology Department of the National Hospital of Niamey, as well Monsieur Ibrahim Oumarou Sadou of the National Institute of Statistics, for their contributions.

\section{REFERENCES}

1. Lapeyssonnie, L., 1963. La meningite cerebrospinale en Afrique. Bulletin of the World Health Organization, Volume 28, Rome, Italy, pp: 114.

2. Chonmaitree, T. and S. Baron, 1991. Bacteria and viruses induce production of interferon in the cerebrospinal fluid of children with acute meningitis: A study of 57 cases and review. Rev. Infect. Dis., 13: 1061-1065.

3. Tang, R.B., B.H. Lee, R.L. Chung, S.J. Chen and T.T. Wong, 2001. Interleukin- $1 \beta$ and tumor necrosis factor- $\alpha$ in cerebrospinal fluid of children with bacterial meningitis. Child's Nervous Syst., 17: 453-456.

4. Hsieh, C.C., J.H. Lu, S.J. Chen, C.C. Lan, W.C. Chow and R.B. Tang, 2009. Cerebrospinal fluid levels of interleukin-6 and interleukin-12 in children with meningitis. Child's Nervous Syst., 25: 461-465. 
5. Garcia-Hernandez, P., B. Prieto, E. Martinez-Morillo, V. Rodriguez and F.V. Alvarez, 2016. Interleukin-6 in cerebrospinal fluid as a biomarker of acute meningitis. Ann. Clin. Biochem., 53: 155-163.

6. Yao, R., Y. Cao, Y. Chen and Z. Zeng, 2015. Diagnostic performance of interleukin-6 and interleukin-8 for bacterial meningitis: A meta-analysis. Int. J. Clin. Exp. Med., 8: 7059-7068.

7. Prasad, R., R. Kapoor, R. Srivastava, O.P. Mishra and T.B. Singh, 2014. Cerebrospinal fluid TNF- $\alpha$, IL- 6 and IL- 8 in children with bacterial meningitis. Pediatr. Neurol., 50: 60-65.

8. Seehusen, D.A., M.M. Reeves and D.A. Fomin, 2003. Cerebrospinal fluid analysis. Am. Family Physician, 68: 1103-1108.

9. Wilson, R. and A.P.F. Turner, 1992. Glucose oxidase: An ideal enzyme. Biosens. Bioelectron., 7: 165-185.

10. Bankar, S.B., M.V. Bule, R.S. Singhal and L. Ananthanarayan, 2009. Glucose oxidase-An overview. Biotechnol. Adv., 27: 489-501.

11. Young, D.S. and R.B. Friedman, 2001. Effects of Disease on Clinical Laboratory Tests. 4th Edition, Vol. 1, 2. AACC Press, Washington, DC.USA., ISBN-13: 9781890883454, pp:682-683.

12. Orsonneau, J.L., P. Douet, C. Massoubre, P. Lustenberger and S. Bernard, 1989. An improved pyrogallol red-molybdate method for determining total urinary protein. Clin. Chem., 35: 2233-2236.

13. Johnson, A.M., E.M. Rohlfs and L.M. Silverman, 1999. Proteins. In: Tietz Textbook of Clinical Chemistry, Burtis, C.A. and E.R. Ashwood (Eds.). 3rd Edn., W.B. Saunders Co., Philadelphia USA., pp: 477-540.

14. Chan, D.W.Y. and M.T. Perlstein, 1987. Immunoassay: A Practical Guide. Academic Press, New York, USA., ISBN13: 9780121676353 , Pages: 167.

15. Taha, M.K., 2000. Simultaneous approach for nonculture PCR-based identification and serogroup prediction of Neisseria meningitidis. J. Clin. Microbiol., 38: 855-857.

16. Giorgini, D., M. Ducos-Galand, J.M. Alonso and M.K. Taha, 2004. [Molecular diagnosis of Neisseria meningitidis]. Revue Francaise Laboratoires, 362: 33-35, (In French).

17. Chanteau, S., F. Sidikou, S. Djibo, A. Moussa, H. Mindadou and P. Boisier, 2006. Scaling up of PCR-based surveillance of bacterial meningitis in the African meningitis belt: Indisputable benefits of multiplex PCR assay in Niger. Trans. R. Soc. Trop. Med. Hyg., 100: 677-680.

18. Tunkel, A.R., B.J. Hartman, S.L. Kaplan, B.A. Kaufman, K.L. Roos, W.M. Scheld and R.J. Whitley, 2004. Practice guidelines for the management of bacterial meningitis. Clin. Infect. Dis., 39: 1267-1284.

19. Bonadio, W.A., 1992. The cerebrospinal fluid: Physiologic aspects and alterations associated with bacterial meningitis. Pediatr. Infect. Dis. J., 11: 423-432.
20. Kepa, L., B. Oczko-Grzesik and A. Boron-Kaczmarska, 2014. Cerebrospinal fluid interleukin-6 concentration in patients with purulent, bacterial meningitis-own observations. Przeglad Epidemiologiczny, 68: 645-649.

21. Takahashi, W., T.A. Nakada, R. Abe, K. Tanaka, Y. Matsumura and S. Oda, 2014. Usefulness of interleukin 6 levels in the cerebrospinal fluid for the diagnosis of bacterial meningitis. J. Crit. Care, 29: 693.e1-693.e6.

22. Kim, K.S., C.A. Wass and A.S. Cross, 1997. Blood-brain barrier permeability during the development of experimental bacterial meningitis in the rat. Exp. Neurol., 145: 253-257.

23. Tunkel, A.R. and W.M. Scheld, 1993. Pathogenesis and pathophysiology of bacterial meningitis. Clin. Microbiol. Rev., 6: 118-136.

24. Dulkerian, S.J., L. Kilpatrick, A.T. Costarino Jr., L. McCawley and J. Fein et al., 1995. Cytokine elevations in infants with bacterial and aseptic meningitis. J. Pediatr., 126: 872-876.

25. Chavanet, P., B. Bonnotte, M. Guiguet, V. Zeller and E. Solary et al., 1992. High concentrations of intrathecal interleukin-6 in human bacterial and nonbacterial meningitis. J. Infect. Dis., 166: 428-431.

26. Vazquez, J.A., M.D.C. Adducci, C. Coll, D.G. Monzon and K.V. Iserson, 2012. Acute meningitis prognosis using cerebrospinal fluid interleukin-6 levels. J. Emerg. Med., 43: 322-327.

27. Misra, U.K., J. Kalita, R. Srivastava, P.P. Nair, M.K. Mishra and A. Basu, 2010. A study of cytokines in tuberculous meningitis: clinical and MRI correlation. Neurosci. Lett., 483: 6-10.

28. Scheld, M.W., U. Koedel, B. Nathan and H.W. Pfister, 2002. Pathophysiology of bacterial meningitis: Mechanism(s) of neuronal injury. J. Infect. Dis., 186: S225-S233.

29. Gruol, D.L. and T.E. Nelson, 1997. Physiological and pathological roles of interleukin- 6 in the central nervous system. Mol. Neurobiol., 15: 307-339.

30. Tunkel, A.R., B. Wispelwey and W.M. Scheld, 1990. Bacterial meningitis: Recent advances in pathophysiology and treatment. Ann. Internal Med., 112: 610-623.

31. Nudelman, Y. and A.R. Tunkel, 2009. Bacterial meningitis: Epidemiology, pathogenesis and management update. Drugs, 69: 2577-2596.

32. Wang, S.M., H.Y. Lei, L.Y. Su, J.M. Wu, C.K. Yu, J.R. Wang and C.C. Liu, 2007. Cerebrospinal fluid cytokines in enterovirus 71 brain stem encephalitis and echovirus meningitis infections of varying severity. Clin. Microbiol. Infect., 13: 677-682.

33. Mook-Kanamori, B.B., M. Geldhoff, T. van der Poll and D. van de Beek, 2011. Pathogenesis and pathophysiology of pneumococcal meningitis. Clin. Microbiol. Rev., 24: 557-591.

34. Ministry of Public Health of Niger, 2015. Rapport MDO S22 sur la gestion de l'epidemie de meningite de 2015 au Niger. https://www.humanitarianresponse.info/en/system/files/d ocuments/files/sitrep_meningite_journee_1_06_2015_vf.pdf 